\title{
Development of an Adaptive \\ Trajectory Tracking Control of Wheeled Mobile Robot
}

Guiovanny Suarez-Rivera; Nelson-David Muñoz-Ceballos; HenryMauricio Vásquez-Carvajal

Citation: G. Suarez-Rivera, N.-D. Muñoz-Ceballos, H.-M. VásquezCarvajal, "Development of an Adaptive Trajectory Tracking Control of Wheeled Mobile Robot," Revista Facultad de Ingeniería, vol. 30 (55), e12022, 2021. https://doi.org/10.19053/01211129.v30.n55.2021.12022

Received: November 01, 2020; Accepted: February 12, 2021;

Published: February 13, 2021

Copyright: This is an open access article distributed under license $\underline{\mathrm{CC}}$

BY

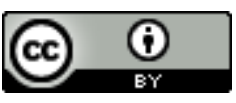

Conflict of interest: The authors state there is no conflict of interest. 


\title{
Development of an Adaptive Trajectory Tracking Control of Wheeled Mobile Robot
}

\author{
Guiovanny Suarez-Rivera ${ }^{1}$ \\ Nelson-David Muñoz-Ceballos² \\ Henry-Mauricio Vásquez-Carvajal ${ }^{3}$
}

\begin{abstract}
Classical modeling and control methods applied to differential locomotion mobile robots generate mathematical equations that approximate the dynamics of the system and work relatively well when the system is linear in a specific range. However, they may have low accuracy when there are many variations of the dynamics over time or disturbances occur. To solve this problem, we used a recursive least squares (RLS) method that uses a discrete-time structure first-order autoregressive model with exogenous variable (ARX). We design and modify PID adaptive self-adjusting controllers in phase margin and pole allocation. The main contribution of this methodology is that it allows the permanent and online update of the robot model and the parameters of the adaptive self-adjusting PID controllers. In addition, a Lyapunov stability analysis technique was implemented for path and trajectory tracking control, this makes the errors generated in the positioning and orientation of the robot when performing a given task tend asymptotically to zero. The performance of the PID adaptive self-adjusting controllers is measured through the implementation of the criteria of the integral of the error, which allows to
\end{abstract}

\footnotetext{
1 Instituto Tecnológico Metropolitano (Medellín-Antioquia, Colombia). guiovannysuarez97899@correo.itm.edu.co. ORCID: 0000-0003-4131-9280

2 M. Sc. Politécnico Colombiano Jaime Isaza Cadavid (Medellín-Antioquia, Colombia). ndmunoz@elpoli.edu.co. ORCID: 0000-0002-4696-8151

$3 \mathrm{M}$ Sc. Instituto Tecnológico Metropolitano (Medellín-Antioquia, Colombia). henryvasquez@itm.edu.co. ORCID: 0000-0001-5428-0253
}

Revista Facultad de Ingeniería (Rev. Fac. Ing.) Vol. 30 (55), e12022. January-March 2021. Tunja-Boyacá, 
determine the controller of best performance, being in this case, the PID adaptive self-adjusting type in pole assignment, allowing the mobile robot greater precision in tracking the trajectories and paths assigned, as well as less mechanical and energy wear, due to its smooth and precise movements.

Keywords: Lyapunov stability; Matlab; mobile robots; parametric model; simulation; telerobotics.

\section{Desarrollo de un control adaptivo para el seguimiento de trayectoria de un robot móvil con ruedas}

\section{Resumen}

Los métodos clásicos de modelamiento y control aplicados a robots móviles de locomoción diferencial generan ecuaciones matemáticas que representan con aproximación la dinámica del sistema y funcionan relativamente bien cuando el sistema es lineal en un rango específico de trabajo. Sin embargo, pueden presentar baja precisión cuando hay muchas variaciones de la dinámica en el tiempo o se presentan perturbaciones. Para solucionar este problema se empleó un método recursivo de mínimos cuadrados (RLS) que usa una estructura en tiempo discreto de primer orden del modelo autorregresivo con variable exógena (ARX). Se realiza el diseño y sintonización de controladores autoajustables adaptativos PID en margen de fase y en asignación de polos. El principal aporte de esta metodología es que permite la actualización permanente y en línea (on-line) del modelo del robot y de los parámetros de los controladores autoajustables adaptativos PID, además, se implementó una técnica de análisis de estabilidad de Lyapunov para el control de seguimiento de trayectorias y de caminos, esto hace que los errores generados en el posicionamiento y la orientación del robot al realizar una determinada tarea tiendan asintóticamente a cero. El desempeño de los controladores autoajustables adaptativos PID es medido a través de la implementación de los criterios de la integral del error, lo cuales permiten determinar el controlador de mejor rendimiento, siendo para este caso el del tipo autoajustable adaptivo PID en asignación de polos, permitiendo al robot móvil mayor precisión en el seguimiento de las trayectorias y caminos asignados, así 
como un menor desgaste mecánico y energético, debidos a sus movimientos suaves y precisos.

Palabras clave: estabilidad de Lyapunov; Matlab; modelo paramétrico; robots móviles; simulación; telerobótica.

\section{Desenvolvimento de um controle adaptativo para rastrear a trajetória de um robô móvel com rodas}

\section{Resumo}

Os métodos clássicos de modelagem e controle aplicados a robôs móveis de locomoção diferencial geram equações matemáticas que aproximam a dinâmica do sistema e funcionam relativamente bem quando o sistema é linear em uma faixa específica de trabalho. Porém, podem apresentar baixa precisão quando há muitas variações da dinâmica ao longo do tempo ou quando ocorrem distúrbios. Para resolver este problema, foi utilizado um método recursivo de mínimos quadrados (RLS) que utiliza uma estrutura de tempo discreta de primeira ordem do modelo autorregressivo com variável exógena (ARX). O projeto e o ajuste dos controladores autoajustáveis adaptativos PID são realizados na margem de fase e na atribuição de pólos. A principal contribuição desta metodologia é que ela permite a atualização permanente e online do modelo do robô e dos parâmetros dos controladores PID adaptativos autoajustáveis, além disso, foi implementada uma técnica de análise de estabilidade de Lyapunov para controle de trajetória e rastreamento de caminho, o que torna os erros gerados no posicionamento e orientação do robô ao realizar determinada tarefa assintoticamente tendem a zero. $O$ desempenho dos controladores autoajustáveis PID adaptativos é medido através da implementação do critério integral de erro, que permite determinar o controlador de melhor desempenho, sendo neste caso o tipo PID autoajustável adaptativo na atribuição de pólos, permitindo ao robô móvel, maior precisão no seguimento das trajetórias e caminhos atribuídos, bem como menor desgaste mecânico e energético, devido aos seus movimentos suaves e precisos.

Palavras-chave: Estabilidade de Lyapunov; Matlab; modelo paramétrico; robôs móveis; simulação; telerobótica. 


\section{INTRODUCTION}

Generally, studies on trajectory tracking of mobile robots are based on classical mathematical models described in the literature, which represent in a very simplified way the kinematics of the robot, such as [1, 2]. In some cases, mathematical equations are included that roughly represent the dynamics of the system [3]. These equations work relatively well when the system is linear in a specific range, as proposed by Alves [4], the mathematical model of the motors of the traction system is only obtained from physical laws, so the model may present low accuracy when there are many variations of the system dynamics over time, uncertainty or disturbances.

Related works try to solve this problem in different ways, some authors focus on analyzing the impact of parametric uncertainties of a kinematic model on the estimation of the speed and pose of the robot, which provides important information for the design of the controllers [5]. Abdelwahab [6] presents a rule-based heuristic control system with fuzzy logic, which has proven to be useful in addressing uncertainty and imprecision to achieve robust and smooth trajectory tracking. Ortigoza [7] also proposes as a strategy to develop models and controllers for each subsystem that makes up the robot, including the power stage. Dobribarsci [8] proposes the identification of motors up to the design of linear and non-linear controllers. In these and other articles it is common that the models obtained do not include updates over time.

The objective of the research is to present a methodology for the identification, modeling and optimal control of a mobile robot in trajectory tracking tasks [9], for which online identification is performed, that is, the model is being updated in real time, constituting a significant contribution to making the model and robot controllers more accurate. A discrete-time parametric model is used, among which the autoregressive model with exogenous variable ARX $[10,11]$ stands out.

This article is structured as follows: section 2 describes the hardware, software and methodology used for identification, mathematical modeling and control, section 3 presents the results and analysis, section 4 presents the conclusions. 


\section{Materials ANd Methods}

This section describes the hardware and software materials, and the methodology for identifying, modeling, and controlling the robot for trajectory tracking missions.

\section{A. Mobile Robot}

With the Lego Mindstorms EV3 [12] educational kit, a differential locomotion mobile robot was built, as shown in figure 1 .

\section{B. Software}

The following software was used in the development of the project:

1. Operating system Microsoft Windows 10 professional.

2. Mathworks Matlab R2015a

3. Simulink Support Packaged for hardware Lego EV3.

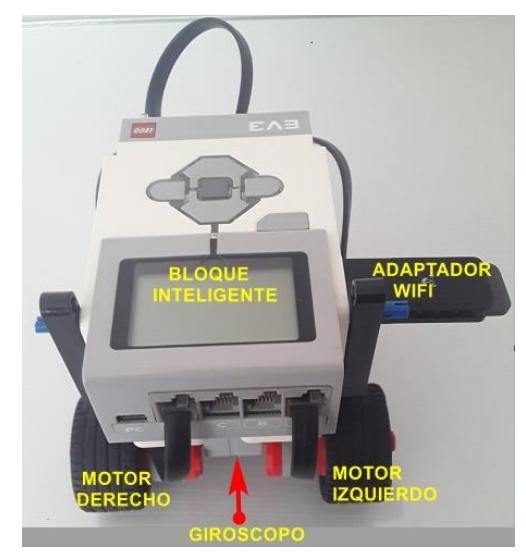

Fig. 1. Components of the Lego EV3 robot used.

\section{Identification, Modeling and Control}

1) Direct Kinematics of the Mobile Robot. To obtain the kinematic behavior data of the differential robot, it is assumed that the robot moves on a flat surface without friction, that it moves only by the rotational motion of the wheels, that it is considered as a solid, rigid mechanism without flexible parts, but that the holonomic constraints of the system must be considered [13-14], that is, it cannot move to the sides, as shown in figure 2. 


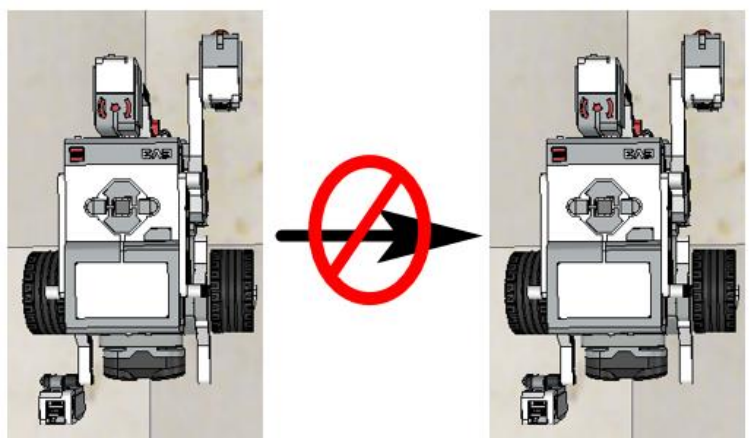

Fig. 2. Holonomic constraints of the differential robot.

The measurements of interest in the modeling process are the distance between the wheels, called $L$ and the radius of the wheels, called $R$, as shown in figure 3 .

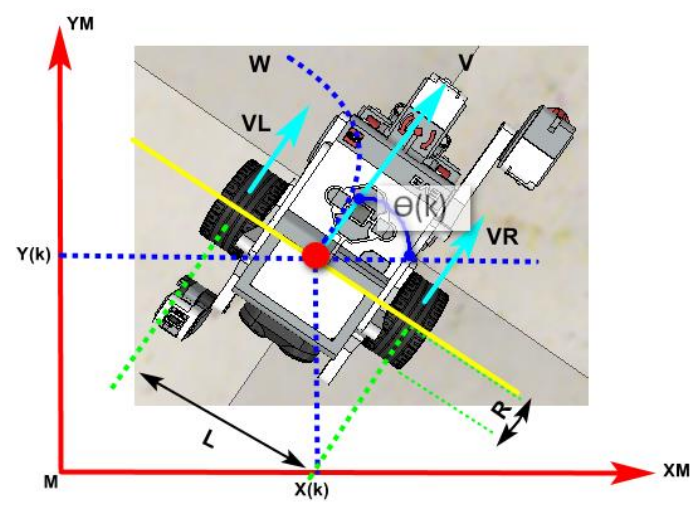

Fig. 3. Physical variables of the differential drive robot.

To achieve precise movement, control must be exercised over the right and left wheel velocities, VR and VL, which affect the states of the system $x, y, \Theta$. The robot's linear and angular velocities are defined in equations (1) and (2), from which equations (3), (4) and (5) define the kinematics of the robot's motion on each axis.

$$
\begin{gathered}
\mathrm{V}=\mathrm{R} \frac{\mathrm{V}_{\mathrm{r}}+\mathrm{V}_{\mathrm{i}}}{2} \\
\mathrm{~W}=\mathrm{R} \frac{\mathrm{V}_{\mathrm{r}}-\mathrm{V}_{\mathrm{i}}}{\mathrm{L}} \\
\dot{\mathrm{X}}=\mathrm{V} * \cos \theta \\
\dot{\mathrm{Y}}=\mathrm{V} * \sin \theta \\
\dot{\theta}=\mathrm{W} \\
w_{r}=\frac{\dot{X}}{R} * \cos \theta+\frac{\dot{Y}}{R} * \sin \theta+\frac{L}{2 R} * \dot{\theta} \\
w_{l}=\frac{\dot{X}}{R} * \cos \theta+\frac{\dot{Y}}{R} * \sin \theta-\frac{L}{2 R} * \dot{\theta}
\end{gathered}
$$

Revista Facultad de Ingeniería (Rev. Fac. Ing.) Vol. 30 (55), e12022. January-March 2021. Tunja-Boyacá, Colombia. L-ISSN: 0121-1129, e-ISSN: 2357-5328. 
Where $\mathrm{v}$ is the linear velocity, $\theta$ is the angle of orientation, $\dot{\theta}$ and $\mathrm{W}$ are the angular velocity. Equation (8) denotes the kinematic of the vehicle's motion. With the direct kinematic model of the robot, the control system for tracking the trajectory is developed.

$$
\left[\begin{array}{c}
\dot{\mathrm{X}} \\
\dot{\mathrm{Y}} \\
\dot{\theta}
\end{array}\right]=\left[\begin{array}{cc}
\mathrm{R} \frac{\cos \theta}{2} & \mathrm{R} \frac{\cos \theta}{2} \\
\mathrm{R} \frac{\sin \theta}{2} & \mathrm{R} \frac{\sin \theta}{2} \\
\frac{\mathrm{R}}{\mathrm{L}} & -\frac{\mathrm{R}}{\mathrm{L}}
\end{array}\right] *\left[\begin{array}{l}
\mathrm{W}_{\mathrm{r}} \\
\mathrm{W}_{\mathrm{l}}
\end{array}\right]
$$

2) Inverse Kinematics of the Mobile Robot. To control the movement of the robot, the angular velocities of the robot wheels are altered, which are determined from the desired linear and angular velocities, which are represented by equation (9).

$$
\left[\begin{array}{l}
\mathrm{W}_{\mathrm{r}} \\
\mathrm{W}_{\mathrm{l}}
\end{array}\right]=\left[\begin{array}{ccc}
\frac{\cos \theta}{\mathrm{R}} & \frac{\sin \theta}{\mathrm{R}} & \frac{\mathrm{L}}{\mathrm{R}} \\
\frac{\cos \theta}{\mathrm{R}} & \frac{\sin \theta}{\mathrm{R}} & -\frac{\mathrm{L}}{\mathrm{R}}
\end{array}\right] *\left[\begin{array}{c}
\dot{\mathrm{X}} \\
\dot{\mathrm{Y}} \\
\dot{\theta}
\end{array}\right]
$$

3) Motors Identification, Modeling and Control. For the modeling of the engines, an on-line identification method is used, with a recursive least square RLS algorithm and autoregressive parametric model with exogenous variable ARX of first order. For each motor, a self-adjusting PID adaptive controller is implemented in pole assignment. The RLS algorithm constantly updates the ARX model of the motors and the parameters of the adaptive controllers, allowing more accurate system response. Each motor control transfer function is shows in equations (10) and (11) and their Simulink implementation is shown in figure 4.

$$
\begin{aligned}
G_{c} A(z) & =\frac{-1.6006 z^{2}+2.8942 z-0.8990}{z^{2}-1} \\
G_{c} D(z) & =\frac{-1.2805 z^{2}+2.3154 z-0.7192}{z^{2}-1}
\end{aligned}
$$




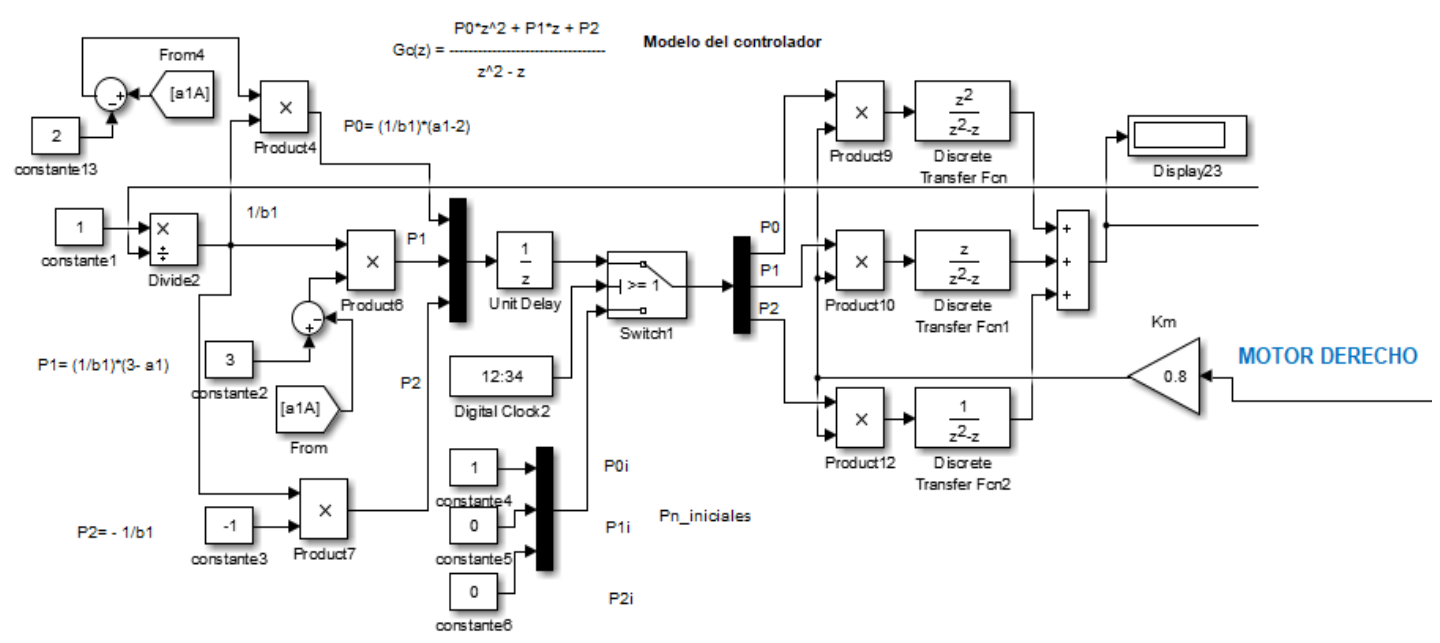

Fig. 4. PID self-adjusting adaptive controller in pole assignment.

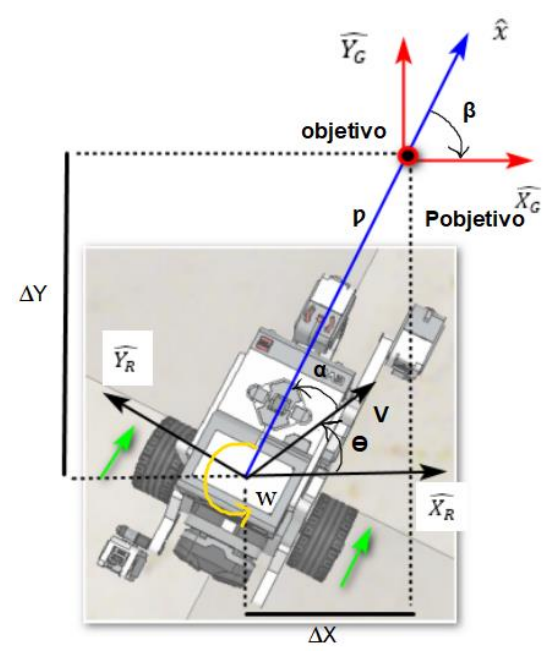

Fig. 5. Kinematics of the robot between each point.

In this representation, the position error vector is given by equation (12).

$$
e=R_{[x, y, \theta]^{T}}
$$

This error corresponds to the robot's reference system $\left\{\widehat{X_{R}}, \widehat{Y_{R}}, \theta\right\}$, where $\widehat{Y_{G}}, \widehat{X_{G}}$, are the coordinates of the target. If $\alpha \in \mathrm{I}$, where:

$$
I=\left(-\frac{\pi}{2}, \frac{\pi}{2}\right]
$$

Applying transformation to polar coordinates considering as its origin the objective point, we obtain:

$$
\begin{aligned}
& p=\sqrt{\Delta x^{2}+\Delta y^{2}} \\
& \alpha=-\theta+\operatorname{atan} 2\left(\frac{\Delta y}{\Delta x}\right)
\end{aligned}
$$

Revista Facultad de Ingeniería (Rev. Fac. Ing.) Vol. 30 (55), e12022. January-March 2021. Tunja-Boyacá, Colombia. L-ISSN: 0121-1129, e-ISSN: 2357-5328. 


$$
\beta=-\theta-\alpha
$$

Where $\mathrm{p}$ is the distance between the moving robot and the target, $\alpha$ is the angle needed to orient the robot towards the target point. Finally, $\beta$ is the angle of orientation of the robot with respect to the coordinate system of the target point.

The task of controller design is to find a control matrix, which is given by equation (17), in equation (18) the control action is expressed.

$$
\begin{aligned}
& \mathrm{K}=\left[\begin{array}{lll}
\mathrm{k}_{11} & \mathrm{k}_{12} & \mathrm{k}_{13} \\
\mathrm{k}_{21} & \mathrm{k}_{22} & \mathrm{k}_{23}
\end{array}\right] \\
& {\left[\begin{array}{c}
V \\
W
\end{array}\right]=K * e=K * R_{[x, y, \theta]^{T}}}
\end{aligned}
$$

4) Trajectory Tracking Control. For the trajectory tracking is proposed a Lyapunov control algorithm, based on the robot kinematic model, to generate the signals of the speed and orientation angle, with which the mobile robot is intended to follow the coordinated points $\mathrm{x}$ and $\mathrm{y}$ of the reference trajectory previously described in Matlab and transmitted via $\mathrm{Wi}-\mathrm{Fi}$ from the computer. Figure 5 shows the kinematic parameters to be considered between each point of the robot's trajectory. Equations (19) and (20) represent autoregressive models with exogenous variable for each motor.

$$
\begin{aligned}
& G_{p} A(z)=\frac{1.252}{z-0.128} \\
& G_{p} D(z)=\frac{1.226}{z-0.156}
\end{aligned}
$$

Figure 6 shows the implementation in Simulink of equations 14, 15, 16, and the path generator in the Matlab function block.

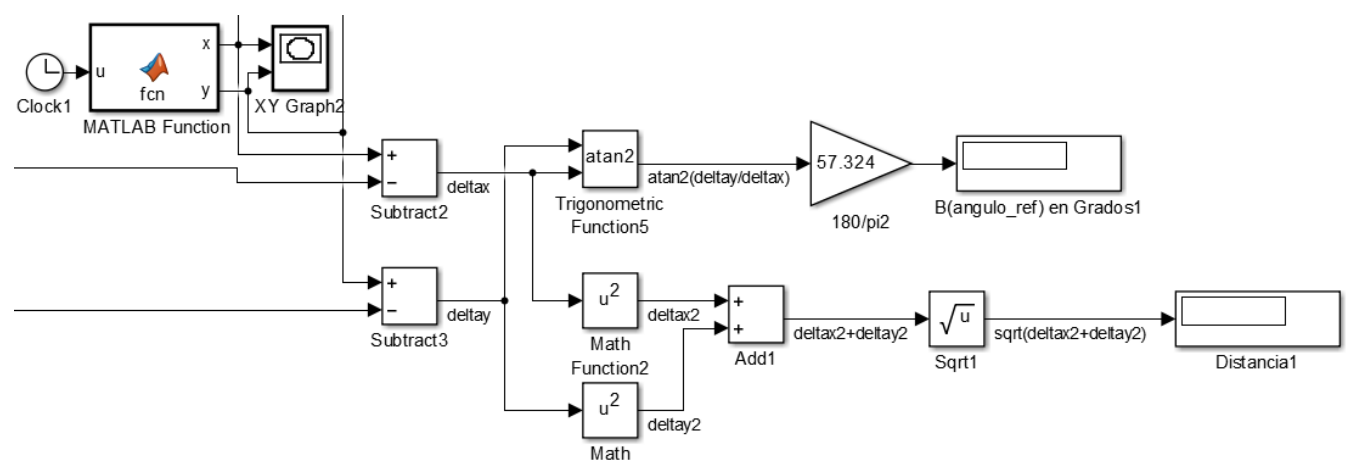

Fig. 6. trajectory generator with the parameters $p$ y $\beta$. 

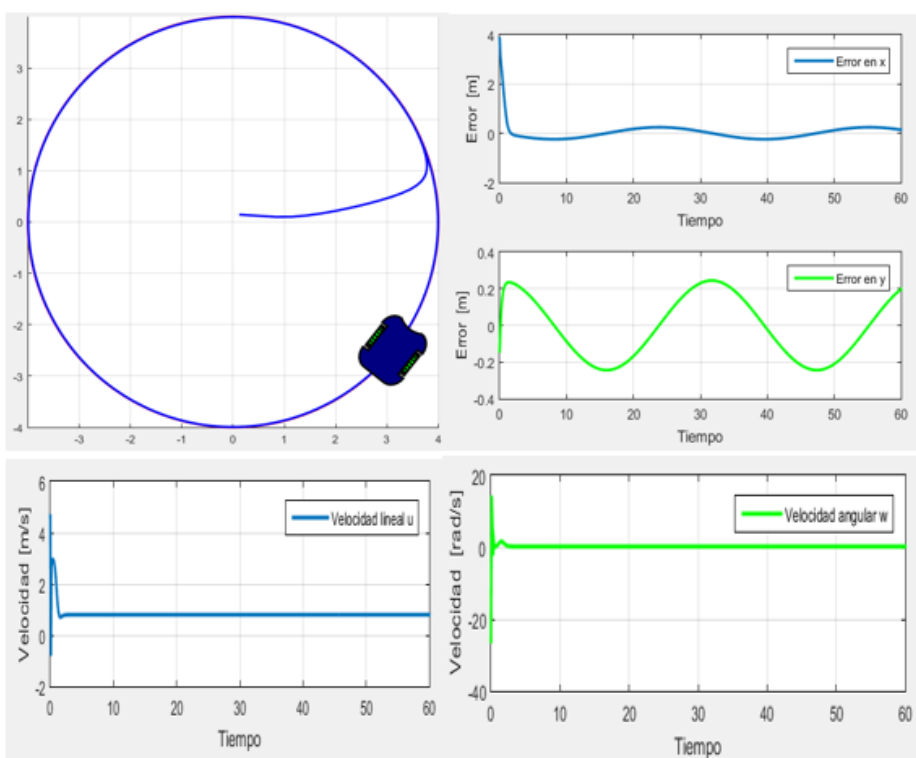

Fig. 7. Simulation of the Lyapunov circular path tracking controller.

For the modeling and simulation of the trajectory points tracking control of the mobile robot, equations (19) and (20) for the linear and angular speeds control of the mobile robot were implemented in Simulink. Figure 7 shows the result of the validation and simulation of the trajectory tracking by Lyapunov.

$$
\begin{aligned}
& V=K_{1} * \cos (\alpha) * \rho \\
& W=K_{2} * \alpha+K_{1} * \cos (\alpha) * \sin (\alpha) *\left(\alpha+q_{2} * \beta\right) / \alpha
\end{aligned}
$$

$$
\begin{aligned}
& \operatorname{con} K_{1}>0 \\
& \text { con } K_{2}>0
\end{aligned}
$$

Figure 8 shows the forward and inverse kinematics of the differential drive robot.

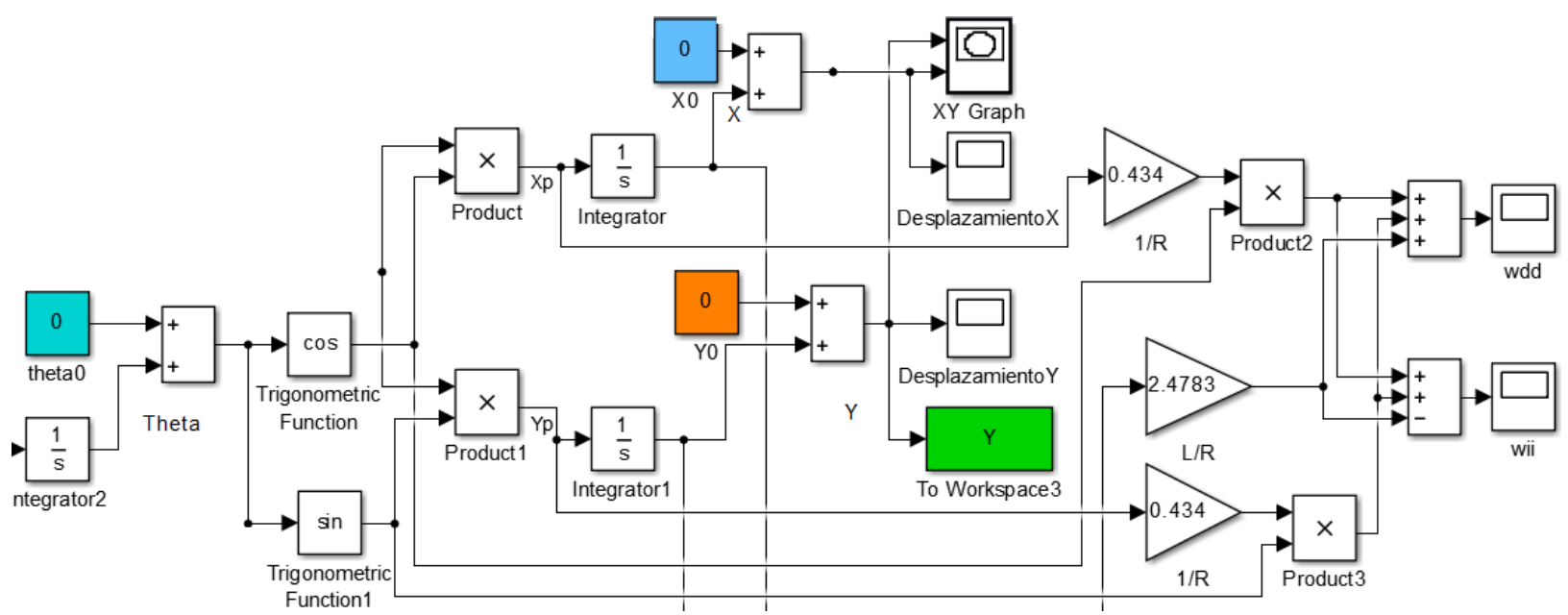

Fig. 8. Forward and inverse kinematics differential drive robot. 


\section{Results AND ANALysis}

the figure 9 shows the trajectory tracking results of the real robot, there is a certain margin of error at the beginning of the trajectory of the mobile robot, this is due to the initial values present in the matrix $k$, equation (17). For the circular trajectory, where the robot starts from position $(0,0)$, and $0^{\circ}$ orientation degrees, it is observed that the robot requires more time to reach the desired trajectory, the opposite happens for the straight-line trajectory, it influences the computational expenditure by the processing system and energy consumption by the traction system. Table 1 shows the criterias of the error integral [15] used for selecting the PID adaptive controller. the controller that has the best results is the self-adjusting adaptive in pole assignment.

Tabla 1. Selection criteria PID self-adjusting adaptive controller.

\begin{tabular}{|c|c|c|c|}
\hline Motor & Criteria & $\begin{array}{c}\text { Self-adjustable controller } \\
\text { in phase margin }\end{array}$ & $\begin{array}{c}\text { Self-adjusting controller } \\
\text { in pole allocation }\end{array}$ \\
\hline \multirow{3}{*}{$\mathrm{A}$} & $\mathrm{IAE}$ & 29.57 & 1.829 \\
\cline { 2 - 4 } & $\mathrm{I} E$ & 736.3 & 17.31 \\
\cline { 2 - 4 } & $\mathrm{IAET}$ & 15.64 & 0.077 \\
\hline \multirow{3}{*}{$\mathrm{D}$} & $\mathrm{IAE}$ & 29.65 & 1.798 \\
\cline { 2 - 4 } & $\mathrm{ICE}$ & 736.8 & 17.16 \\
\cline { 2 - 4 } & $\mathrm{IAET}$ & 15.73 & 0.104 \\
\hline
\end{tabular}
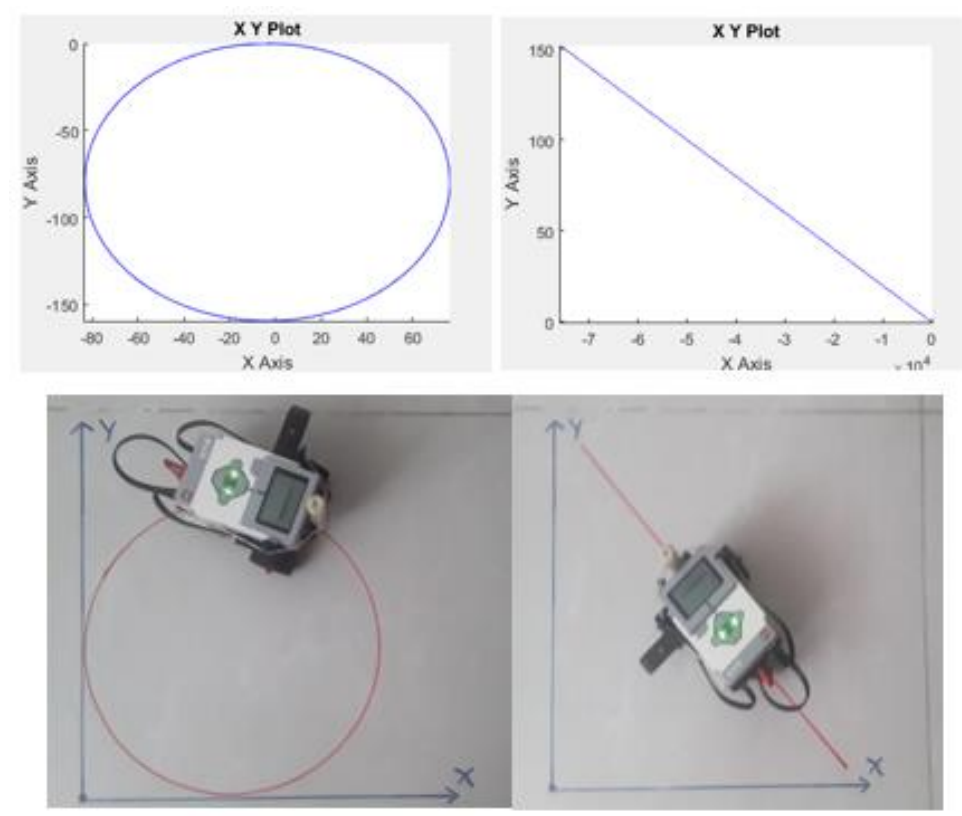

Fig. 9. Tracking of circular and straight trajectories. 


\section{CONCLUSIONS}

The methodology of identification, modeling and control presented in this article allows the permanent online update of the locomotion system engine models, as well as the parameters of the controllers designed to track the trajectories of the differential drive robot, which is an advantage because it achieves more accurate system response compared to traditional identification, modeling and control techniques that have a limited range of operation.

The online identification method implemented allows knowing at any instant of time the mathematical model of the motors, an aspect that is not possible in those techniques where the model is only obtained from physical laws.

The online parameters update of the trajectory tracking controllers, allows movements with precision and smoothness, compared to results obtained with the classic PID controllers evaluated. The execution of smooth trajectories is associated with less control effort and lower energy consumption [16].

The implementation of controllers from the Lyapunov stability analysis, facilitates to the system to work optimally in the event of unexpected changes or disturbances, consequently, the robot may have a better cost-benefit ratio in energy consumption, smoothness of the trajectory, precision of movements, etc.

The proposed methodology provides a strategy to solve path and trajectory tracking control missions. Simulations and experiments were performed in real environments to verify their robustness and efficiency. In addition, taking mathematical models to first-order systems favors the low computational cost of the proposed solution.

\section{AUTHOR's CONTRIBUTION}

Guiovanny Suarez-Rivera: Conceptualization, Investigation, Methodology, Writing - Original draft.

Nelson-David Muñoz-Ceballos: Methodology, Writing - Review \& Editing. Henry-Mauricio Vásquez-Carvajal: Methodology, Writing - Review \& Editing. 


\section{REFERENCES}

[1] G. Cook, F. Zhang, "Kinematic Models for Mobile Robots," in Mobile Robots: Navigation, Control and Sensing, Surface Robots and AUVs, 2019, pp. 5-12. https://doi.org/10.1002/9781119534839.ch1

[2] M. Ben-Ari, F. Mondada, Elements of Robotics, Springer, Switzerland, 2018.

[3] R. Bibi, B. S. Chowdhry, R. A. Shah, "PSO based localization of multiple mobile robots employing LEGO EV3," in International Conference on Computing, Mathematics and Engineering Technologies, Sukkur, 2018, pp. 1-5. https://doi.org/10.1109/icomet.2018.8346452

[4] T. G. Alves, W. F. Lages, R. V. Henriques, "Parametric Identification and Controller Design for a Differential-Drive Mobile Robot," IFAC-PapersOnLine, vol. 51, no. 15, pp. 437-442, 2018. https://doi.org/10.1016/j.ifacol.2018.09.184

[5] J. G. N. D. Carvalho Filho, E. Á. N. Carvalho, L. Molina, E. O. Freire, "The Impact of Parametric Uncertainties on Mobile Robots Velocities and Pose Estimation," IEEE Access, vol. 7, pp. 69070-69086, 2019. https://doi.org/10.1109/access.2019.2919335

[6] M. Abdelwahab, V. Parque, A. M. R. Fath Elbab, A. A. Abouelsoud, S. Sugano, "Trajectory Tracking of Wheeled Mobile Robots Using Z-Number Based Fuzzy Logic," IEEE Access, vol. 8, pp. 18426-18441, 2020. https://doi.org/10.1109/ACCESS.2020.2968421

[7] L. Fan, Y. Zhang, S. Zhang, "Dynamic Trajectory Tracking Control of Mobile Robot," in 5th International Conference on Information Science and Control Engineering, Zhengzhou, 2018, pp. 728-732. https://doi.org/10.1109/icisce.2018.00156

[8] D. Dobriborsci, A. Kapitonov, N. Nikolaev, "The basics of the identification, localization and navigation for mobile robots," in International Conference on Information and Digital Technologies, Zilina, 2017, pp. 100-105. https://doi.org/10.1109/dt.2017.8024279

[9] A. Kapitonov, E. Antonov, K. Artemov, D. Dobriborsci, E. Zamotaev, A. Karavaev, R. Al-Naim, O. Souzdalev, "Lego Mindstorms EV3 for teaching the basics of trajectory control problems," in IEEE Frontiers in Education Conference, United States, 2018, pp. 1-4. https://doi.org/10.1109/fie.2018.8659322

[10] S. Mokhlis, S. Sadki, B. Bensassi, "System Identification of a DC Servo Motor Using ARX and ARMAX Models," in International Conference on Systems of Collaboration Big Data, Internet of Things \& Security, Morocco, 2019, pp. 1-4. https://doi.org/10.1109/syscobiots48768.2019.9028015

[11] B. Raafiu, P. A. Darwito, "Identification of Four-Wheel Mobile Robot based on Parametric Modelling," in International Seminar on Intelligent Technology and Its Applications, Indonesia, 2018, pp. 397-401. https://doi.org/10.1109/isitia.2018.8710761

[12] M. A. Akmal, N. F. Jamin, N. M. A. Ghani, "Fuzzy logic controller for two wheeled EV3 LEGO robot," in IEEE Conference on Systems, Process and Control, Malacca, 2017, pp. 134-139. https://doi.org/10.1109/spc.2017.8313035

[13] A. Saradagi, V. Muralidharan, V. Krishnan, S. Menta, A. D. Mahindrakar, "Formation Control and Trajectory Tracking of Nonholonomic Mobile Robots," IEEE Transactions on Control Systems Technology, vol. 26, no. 6, pp. 2250-2258, Nov. 2018. https://doi.org/10.1109/tcst.2017.2749563

Revista Facultad de Ingeniería (Rev. Fac. Ing.) Vol. 30 (55), e12022. January-March 2021. Tunja-Boyacá, Colombia. L-ISSN: 0121-1129, e-ISSN: 2357-5328.

DOI: https://doi.org/10.19053/01211129.v30.n55.2021.12022 
[14] A. Ashe, K. M. Krishna, "Dynamic Target Tracking \& Collision Avoidance Behaviour of Person Following Robot Using Model Predictive Control," in 24th International Conference on System Theory, Control and Computing, Romania, 2020, pp. 660-666. https://doi.org/10.1109/icstcc50638.2020.9259720

[15] R. C. Dorf, Modern Control Systems, 13th Edition, Prentice Hall. 2017.

[16] F. Correa. J. Gallardo. N. Muñoz. R. Perez, "Estudio comparativo basado en métricas para diferentes arquitecturas de navegación reactiva," Ingeniare, vol. 24, no. 1, pp. 46-54, Jan. 2016. https://doi.org/10.4067/s0718-33052016000100005

Revista Facultad de Ingeniería (Rev. Fac. Ing.) Vol. 30 (55), e12022. January-March 2021. Tunja-Boyacá, Colombia. L-ISSN: 0121-1129, e-ISSN: 2357-5328. 